\title{
Pengaruh Pemberian Latihan Soal Terstruktur Setelah Pembelajaran Langsung Terhadap Pemahaman Konsep Bilangan Kuantum Pada Siswa Kelas X MIPA SMA Negeri 1 Palangka Raya Tahun Ajaran 2018/2019
}

\author{
Ika Theresia, Abudarin, Nopriawan Berkat Asi \\ Program Studi Pendidikan Kimia, FKIP, Universitas Palangka Raya, Indonesia
}

\begin{abstract}
Abstrak: Tujuan penelitian ini adalah untuk mendeskripsikan Pengaruh Pemberian Latihan Soal Terstruktur Setelah Pembelajaran Langsung Terhadap Pemahaman Konsep Bilangan Kuantum Pada Siswa Kelas X MIPA SMA Negeri 1 Palangka Raya Tahun Ajaran 2018/2019. Penelitian ini merupakan penelitian eksperimen dengan desain penelitian non ekuivalen, pretest-posttest control group design dan melibatkan 53 siswa dari dua kelas X MIPA SMA Negeri 1 Palangka Raya sebagai sampel yang ditentukan dengan teknik cluster random sampling, yaitu kelas X MIPA-7 (kelas eksperimen) sebanyak 28 orang siswa dan siswa kelas X MIPA-6 (kelas kontrol) sebanyak 25 orang siswa. Instrumen yang digunakan berupa soal tes pemahaman tes I dan tes II, latihan soal terstruktur, dan latihan soal. Data tes I diperoleh setelah pembelajaran langsung dan data tes II diperoleh setelah pembelajaran menggunakan latihan soal terstruktur dan latihan soal. Hasil penelitian menunjukkan bahwa $t_{\text {hitung }}>t_{\text {tabel }}(3,06>1,675)$ pada taraf signifikasi $(\alpha) 5 \%$. Hal ini menunjukkan bahwa pemberian latihan soal terstruktur setelah pembelajaran langsung berpengaruh terhadap pemahaman konsep bilangan kuantum pada siswa kelas X MIPA SMAN 1 Palangka Raya tahun ajaran 2018/2019.
\end{abstract}

\section{Kata Kunci: Bilangan Kuantum, Latihan Soal Terstruktur}

\section{Pendahuluan}

Sains merupakan bagian dari kehidupan kita dan kehidupan kita merupakan bagian dari pembelajaran sains (Suyanti, 2010). Ilmu kimia adalah ilmu yang mempelajari tentang materi dan perubahannya (Chang, 2003). Menurut Kean \& Middlecamp (1985), persoalan dalam mempelajari ilmu kimia terkait dengan ciri-ciri ilmu kimia yang diantaranya adalah sebagai berikut: (1) sebagian besar ilmu kimia bersifat abstrak, misalnya atom, molekul, dan ion yang merupakan materi dasar kimia yang tidak tampak. Sifat abstrak ini menuntut siswa untuk membayangkan keberadaan materi tersebut tanpa bisa mengalaminya secara langsung: (2) ilmu kimia merupakan penyederhanaan dari sebenarnya, agar mudah dipelajari maka materi pelajaran kimia disusun berurutan, dan sistematis. Pelajaran kimia merupakan salah satu pelajaran yang memiliki karakteristik tersendiri dan memerlukan keterampilan dalam memecahkan masalah-masalah ilmu kimia yang berupa teori, konsep, hukum, dan fakta (Depdiknas, 2003).

Salah satu subpokok bahasan dalam pelajaran kimia pada kelas X SMA semester ganjil adalah bilangan kuantum. Konsep bilangan kuantum dipelajari tidak hanya sekedar membaca saja, akan tetapi memerlukan pemahaman yang baik untuk memahami konsep tersebut. Salah satu cara yang dapat digunakan untuk membantu guru dalam menuntun dan mengarahkan pola pikir siswa kearah yang benar dalam memahami konsep yang rumit adalah dengan melakukan pembelajaran dengan menggunakan media yaitu latihan soal terstruktur.

Penelitian yang dilakukan Novi Kontesa (2016) tentang Peningkatan Pemahaman Konsep pH Asam Lemah dan Basa Lemah Pasca menggunakan LKS Latihan Terstruktur pada Siswa Kelas XI IPA SMA Nusantara Palangka Raya 
Tahun Ajaran 2015/2016 menyatakan bahwa peningkatan pemahaman konsep pH asam lemah dan basa lemah pasca menggunakan LKS latihan soal terstruktur pada postes I adalah 56,50\% dan postes II adalah 95,97\%. Latihan soal terstruktur dapat dikatakan efektif digunakan untuk mempermudah siswa memahami konsep kimia. Berdasarkan penelitian tersebut, perlu untuk diteliti bagaimana pemahaman siswa dalam memahami konsep Bilangan Kuantum. Penelitian ini diberi judul "Pengaruh Pemberian Latihan Soal Terstruktur Setelah Pembelajaran Langsung Terhadap Pemahaman Konsep Bilangan Kuantum pada Siswa Kelas X MIPA SMA Negeri 1 Palangka Raya Tahun Ajaran 2018/2019”.

Ilmu kimia adalah ilmu yang mempelajari tentang materi dan perubahannya. Dibandingkan dengan mata pelajaran lain, kimia sering terkesan lebih sulit, paling tidak pada tingkat dasar. Belum adanya upaya dan fasilitas sebagai media bahan ajar yang didesain khusus dalam pembelajaran. Materi kimia yang dibahas pada penelitian ini hanya pada subpokok bahasan bilangan kuantum yang dipelajari siswa kelas X SMA. Pokok bahasan Struktur atom yang mencakup materi bilangan kuantum utama (n), bilangan kuantum azimuth (1), bilangan kuantum magnetik (m), dan bilangan kuantum spin (s). Rumusan masalah dalam penelitian ini adalah apakah pemberian latihan soal terstruktur setelah pembelajaran langsung berpengaruh terhadap pemahaman konsep bilangan kuantum pada siswa kelas X MIPA SMAN 1 Palangka Raya Tahun Ajaran 2018/2019? Berdasarkan masalah yang telah dikemukakan, maka tujuan yang akan dicapai dalam penelitian ini adalah mendeskripsikan pengaruh pemberian latihan soal terstruktur setelah pembelajaran langsung terhadap pemahaman konsep bilangan kuantum pada siswa kelas X MIPA SMAN 1 Palangka Raya Tahun ajaran 2018/2019.

\section{Metode Penelitian}

Metode penelitian yang digunakan dalam penelitian ini adalah metode eksperimen. Desain eksperimen penelitian ini adalah Pretest-Posttest Control Group Design yang digambarkan pada Tabel 1.

Tabel 1. Desain Penelitian

\begin{tabular}{ccccc}
\hline Kelompok & $\begin{array}{c}\text { Pembelajar } \\
\text { an }\end{array}$ & $\begin{array}{c}\text { Tes } \\
\text { I }\end{array}$ & $\begin{array}{c}\text { Perlakua } \\
\text { n }\end{array}$ & Tes II \\
\hline Eksperimen $(\mathrm{E})$ & $\mathrm{P}_{1}$ & $\mathrm{X}_{\mathrm{e}}$ & $\mathrm{T}_{1}$ & $\mathrm{Y}_{\mathrm{e}}$ \\
\hline Kontrol $(\mathrm{K})$ & $\mathrm{P}_{1}$ & $\mathrm{X}_{\mathrm{k}}$ & $\mathrm{T}_{2}$ & $\mathrm{Y}_{\mathrm{k}}$ \\
\hline
\end{tabular}

Populasi dalam penelitian ini adalah semua siswa kelas X MIPA Semester ganjil di SMAN 1 Palangka Raya Tahun Ajaran 2018/2019 dengan jumlah siswa adalah 222 siswa yang tersebar dalam 7 kelas. Pengambilan sampel dilakukan dengan menggunakan teknik cluster random sampling. Setelah dilakukan pengundian terpilih dua kelas yaitu kelas X MIPA 7 sebagai kelas eksperimen (28 siswa) dan kelas X MIPA 6 sebagai kelas kontrol (25 siswa).

Soal tes pemahaman konsep tes I dan Tes II dibuat dalam bentuk soal essay tertulis yang berjumlah 4 butir soal. Instrumen penelitian ini dibuat berdasarkan indikator pembelajaran yang ingin dicapai. Instrumen dikembangkan dengan kisi-kisi berdasarkan indikator yang mengacu pada kurikulum 2013 revisi. Soal tes I dan tes II merupakan soal yang berbeda, namun mempunyai bobot yang 
sama. Pada latihan soal terstruktur disusun dengan memberikan langkah-langkah penyelesaian, sedangkan pada latihan soal dirancang tanpa disertai langkahlangkah penyelesaian. Uji coba instrumen dilakukan terhadap kelas lain yang bukan merupakan kelas sampel maupun kelas kontrol yaitu kelas XI MIPA 7 SMA Negeri 1 Palangka Raya dengan Jumlah siswa 33 orang. Uji coba dilakukan untuk mengetahui validitas butir soal, reliabilitas instrumen, indeks kesukaran dan daya beda.

Data yang diperlukan dalam penelitian ini yaitu data kuantitatif berupa skor hasil tes pemahaman konsep siswa kelas X MIPA SMAN 1 Palangka Raya semester ganjil tahun ajaran 2018/2019 dalam menyelesaikan bilangan kuantum. Untuk memperoleh data yang diperlukan dalam penelitian ini, digunakan beberapa metode pengumpulan data, yaitu metode dokumentasi dan metode eksperimen.

Ada 4 tahap yang digunakan dalam pengumpulan dan pengolahan data. Tahap 1, semua kelas sampel diberikan materi pelajaran dengan pembelajaran langsung tentang bilangan kuantum. Tahap 2, kelas diberikan tes I untuk mengetahui (mengukur) pengetahuan hasil belajar seluruh kelas sampel terhadap pengetahuan prasyarat dari materi pelajaran yang akan diberikan pada saat perlakuan. Tahap 3, kelas diberikan latihan soal, kelas eksperimen diberikan latihan soal terstruktur dan kelas kontrol diberikan latihan soal. Tahap 4 adalah tahap pengukuran pemahaman konsep tentang bilangan kuantum. Pengukuran dilakukan dengan pemberian tes II pada kedua kelas yakni kelas eksperimen dan kelas kontrol dan data yang diperoleh kemudian dianalisis dengan teknik analisis data penelitian ini.

Skor yang diperoleh oleh masing-masing siswa dikonversikan dalam bentuk persentase nilai (\%). Normalitas diuji dengan rumus Chi kuadrat. Kriteria

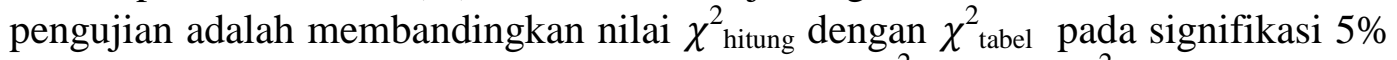
dengan derajat keabsahan db(n-1). Jika harga $\chi_{\text {hitung }}^{2} \leq \chi_{\text {tabel }}^{2}$ berarti data mengikuti distribusi normal. Jika harga $\chi_{\text {hitung }}^{2} \geq \chi_{\text {tabel }}^{2}$ berarti data tidak mengikuti distribusi normal. Uji homogenitas varians dilakukan dengan uji F.

Jika $F_{\text {hitung }} \leq F_{\text {tabel }}$, maka kedua varian tersebut homogen. Jika $F_{\text {hitung }} \geq F_{\text {tabel }}$, maka kedua varian tersebut tidak homogen. $F_{\text {tabel }}$ pada $d b$ pembilang $=\left(n_{1}-1\right)$ dan $d b$ penyebut $=\left(\mathrm{n}_{2}-1\right)$ dangan taraf signifikasi $5 \%$.

Hipotesis statistik untuk uji keseimbangan adalah sebagai berikut:

$\mathrm{H}_{\mathrm{o}}\left(\mu_{1}=\mu_{2}\right)$ : Pemahaman konsep bilangan kuantum hasil pembelajaran langsung siswa kelas X MIPA 7 tidak berbeda dengan siswa kelas X MIPA 6.

$\mathrm{H}_{\mathrm{a}}\left(\mu_{1} \neq \mu_{2}\right)$ : Pemahaman konsep bilangan kuantum hasil pembelajaran langsung siswa kelas X MIPA 7 berbeda dengan siswa kelas X MIPA 6.

$\mu_{1}$ adalah Pemahaman tes I pembelajaran langsung pada kelas eksperimen. $\mu_{2}$ adalah pemahaman tes I pembelajaran langsung pada kelas kontrol. Pengujian hipotesis digunakan rumus uji-t.

$$
t=\frac{\bar{x}_{1}-\bar{x}_{2}}{\sqrt{\frac{\left(n_{1}-1\right) S_{1}^{2}+\left(n_{2}-1\right) S_{2}^{2}}{n_{1}+n_{2}-2}\left(\frac{1}{n_{1}}+\frac{1}{n_{2}}\right)}}
$$

Jika $t_{\text {hitung }}>t_{\text {tabel }}$ pada $\mathrm{db}=\left(\mathrm{n}_{1}+\mathrm{n}_{2}-2\right)$ dan taraf signifikan $5 \%$ maka $\mathrm{H}_{\mathrm{o}}$ ditolak dan $\mathrm{H}_{\mathrm{a}}$ diterima. Jika $\mathrm{t}_{\text {hitung }} \leq \mathrm{t}_{\text {tabel }}$ maka $\mathrm{H}_{\mathrm{o}}$ diterima dan $\mathrm{H}_{\mathrm{a}}$ ditolak.

Hipotesis penelitian dalam penelitian ini digunakan uji $\mathrm{t}$ (dua pihak) dengan taraf signifikan $5 \%$. 
$\mathrm{H}_{\mathrm{o}}\left(\mu_{1}=\mu_{2}\right)$ : Pemberian latihan soal terstruktur setelah pembelajaran langsung tidak berpengaruh terhadap pemahaman konsep bilangan kuantum pada siswa kelas X MIPA SMA Negeri 1 Palangka Raya tahun ajaran 2018/2019.

$\mathrm{H}_{\mathrm{a}}\left(\mu_{1} \neq \mu_{2}\right)$ : Pemberian latihan soal terstruktur setelah pembelajaran langsung berpengaruh terhadap pemahaman konsep bilangan kuantum pada siswa kelas X MIPA SMA Negeri 1 Palangka Raya tahun ajaran 2018/2019.

Pengujian hipotesis penelitian menggunakan tes akhir (tes II) dari kelas eksperimen dan kelas kontrol. $\mu_{1}$ adalah pemahaman konsep bilangan kuantum hasil pembelajaran langsung menggunakan Latihan soal terstruktur. $\mu_{2}$ adalaha pemahaman konsep bilangan kuantum hasil pembelajaran langsung menggunakan Latihan soal. Untuk menguji hipotesis tersebut digunakan uji t (Sugiyono, 2017). Jika $t_{\text {hitung }}>t_{\text {tabel }}$ pada $\mathrm{db}=\left(\mathrm{n}_{1}+\mathrm{n}_{2}-2\right)$ dan taraf signifikan $5 \%$ maka $\mathrm{H}_{\mathrm{o}}$ ditolak dan $\mathrm{H}_{\mathrm{a}}$ diterima. Jika $\mathrm{t}_{\text {hitung }} \leq \mathrm{t}_{\text {tabel }}$ maka $\mathrm{H}_{\mathrm{o}}$ diterima dan $\mathrm{H}_{\mathrm{a}}$ ditolak.

\section{Hasil Penelitian Dan Pembahasan}

Sebelum dilakukan pengambilan data, terlebih dahulu dilakukan simulasi pembelajaran bertujuan untuk melihat kesesuaian butir soal dengan indikator serta kesediaan alokasi waktu. Pelaksanaan simulasi pembelajaran dilakukan di SMA Negeri 1 Palangka Raya pada hari Senin, 10 September 2018 di kelas XI-MIPA 7 berjumlah 33 siswa. Penelitian ini dilakukan terhadap siswa kelas X MIPA SMA Negeri 1 Palangka Raya semester ganjil tahun ajaran 2018/2019.

Pembelajaran dilakukan pada kelas X-MIPA 7 sebagai kelas eksperimen yang diberikan latihan soal terstruktur. Proses pengambilan data penelitian dilaksanakan dengan 1 kali pertemuan dengan alokasi waktu 3 x 45 menit pada hari Jumat, 14 September 2018 yang diikuti oleh 28 orang siswa.

Proses Pengambilan data dilakukan dalam empat tahap. Tahap I pelaksanaan pembelajaran langsung tentang materi bilangan kuantum dilaksanakan selama 30 menit. Tahap II setelah pembelajaran langsung dilakukan pemberian tes I. Pemberian tes I terdiri dari 4 soal essay dan dilakukan selama 25 menit. Tahap III dilaksanakan pembelajaran dengan latihan soal terstruktur yang dilaksanakan selama 35 menit. Tahap IV dilakukan pemberian tes II selama 25 menit. Tujuan dari pemberian tes II untuk mengukur pemahaman siswa setelah pembelajaran menggunakan latihan soal terstruktur.

Pembelajaran dilakukan pada kelas X-MIPA 6 sebagai kelas kontrol yang diberikan latihan soal. Proses pengambilan data penelitian dilaksanakan dengan 1 kali pertemuan dengan alokasi waktu 3 x 45 menit pada hari Selasa, 18 September 2018 yang diikuti oleh 25 orang siswa. Proses Pengambilan data dilakukan dalam empat tahap. Tahap I pelaksanaan pembelajaran langsung tentang materi bilangan kuantum dilaksanakan selama 30 menit. Tahap II setelah pembelajaran langsung dilakukan pemberian tes I. Pemberian tes I terdiri dari 4 soal essay dan dilakukan selama 25 menit. Tahap III dilaksanakan pembelajaran dengan latihan soal yang dilaksanakan selama 35 menit. Tahap IV dilakukan pemberian tes II selama 25 menit. Tujuan dari pemberian tes II untuk mengukur pemahaman siswa setelah pembelajaran menggunakan latihan soal.

Nilai tes I pada kelas eksperimen memiliki nilai terendah 6,67 dan nilai tertinggi 93,33, sedangkan nilai tes II pada kelas eksperimen memiliki nilai 
terendah 33,33 dan tertinggi 100. Mean tes I pada kelas eksperimen adalah 39,29 dan mean tes II pada kelas eksperimen adalah 74,64. Tes I dilaksanakan setelah pembelajaran langsung yang diikuti oleh 28 siswa. Nilai tes I pada kelas eksperimen (X-MIPA 7) memiliki nilai terendah 6,67 dan nilai tertinggi 93,33. Mean nilai pemahaman tes I pada kelas eksperimen adalah 39,29 serta standar deviasinya yaitu 24,37. Distribusi frekuensi tes I kelas eksperimen bahwa nilai rata-rata siswa kelas eksperimen terletak pada interval 36 - 50 sehingga, terdapat $46,43 \%$ atau 13 siswa mendapat nilai dibawah rata-rata dan 53,57\% atau 15 siswa mendapat nilai diatas rata-rata.

Tes II yang dilaksanakan setelah pembelajaran menggunakan latihan soal terstruktur yang diikuti oleh 28 siswa. Nilai tes II pada kelas eksperimen (XMIPA 7) memiliki nilai terendah 33,33 dan nilai tertinggi 100. Mean nilai pemahaman tes II pada kelas eksperimen adalah 74,64 serta standar deviasinya yaitu 18,58. Distribusi frekuensi tes II kelas eksperimen bahwa nilai rata-rata siswa kelas eksperimen terletak pada interval 69 - 80 sehingga, terdapat $28,57 \%$ atau 8 siswa mendapat nilai dibawah rata-rata dan $71,43 \%$ atau 17 siswa mendapat nilai diatas rata-rata.

Nilai tes I pada kelas kontrol memiliki nilai terendah 6,67 dan nilai tertinggi 96,67, sedangkan nilai tes II pada kelas kontrol memiliki nilai terendah 23,33 dan tertinggi 100. Mean tes I pada kelas kontrol adalah 31,73 dan mean tes II pada kelas kontrol adalah 58,33. Tes I dilaksanakan setelah pembelajaran langsung yang diikuti oleh 25 siswa. Nilai tes I pada kelas kontrol (X-MIPA 6) memiliki nilai terendah 6,67 dan nilai tertinggi 96,67. Mean nilai pemahaman tes I pada kelas kontrol adalah 31,73 serta standar deviasinya yaitu 25,82 Distribusi frekuensi tes I kelas kontrol bahwa nilai rata-rata siswa kelas kontrol terletak pada interval $22-37$ sehingga, terdapat $48 \%$ atau 12 siswa mendapat nilai dibawah rata-rata dan $52 \%$ atau 13 siswa mendapat nilai diatas rata-rata.

Tes II yang dilaksanakan setelah pembelajaran langsung yang diikuti oleh 25 siswa. Nilai tes II pada kelas komtrol (X-MIPA 6) memiliki nilai terendah 23,33 dan nilai tertinggi 100. Mean nilai pemahaman tes II pada kelas kontrol adalah 58,53 serta standar deviasinya yaitu 19,69. Distribusi frekuensi tes II kelas kontrol bahwa nilai rata-rata siswa kelas kontrol terletak pada interval $49-61$ sehingga, terdapat $28 \%$ atau 7 siswa mendapat nilai dibawah rata-rata dan $72 \%$ atau 18 siswa mendapat nilai diatas rata-rata.

Perhitungan uji normalitas tes I, pada kelas eksperimen diperoleh nilai $\chi^{2}$ hitung $=7,07$ dengan $\chi^{2}$ tabel $=11,07$, sedangkan pada kelas kontrol diperoleh $\chi^{2}$ hitung $=8,05$ dengan $\chi^{2}$ tabel $=11,07$. Karena $\chi^{2}$ hitung $<\chi^{2}$ tabel maka, dapat disimpulkan data nilai tes I kelas eksperimen dan kelas kontrol berdistribusi normal.

Perhitungan uji normalitas tes II, pada kelas eksperimen diperoleh nilai $\chi^{2}$ hitung $=7,23$ dengan $\chi^{2}$ tabel $=11,07$. Pada kelas kontrol diperoleh $\chi^{2}$ hitung $=$ 8,33 dengan $\chi^{2}$ tabel $=11,07$. Karena $\chi^{2}$ hitung $<\chi^{2}$ tabel maka, dapat disimpulkan data tes II pada kelas eksperimen dan kelas kontrol berdistribusi normal.

Kelas eksperimen memiliki nilai varian $=593,693$ sedangkan kelas kontrol memiliki nilai varian $=666,8$. Hasil perhitungan uji homogenitas dua varian untuk tes I kelas eksperimen dan kelas kontrol, diperoleh $F_{\text {hitung }}=1,123$ dengan taraf signifikan 5\% dengan derajat kebebasan $(n-1)$ dengan nilai $\mathrm{F}_{\text {tabel }}=$ 
1,959, karena $F_{\text {hitung }}<\mathrm{F}_{\text {tabel }}$ maka data nilai tes I kelas eksperimen dan kelas kontrol dinyatakan homogen.

Pada uji homogenitas data tes II kelas eksperimen memiliki nilai varian = 345,158 , sedangkan kelas kontrol memiliki nilai varian $=388,047$. Hasil perhitungan uji homogenitas dua varian untuk data tes II kelas eksperimen dan kelas kontrol, diperoleh $\mathrm{F}_{\text {hitung }}=1,124$ dengan taraf signifikan 5\% dengan derajat kebebasan (n-1) dengan nilai $\mathrm{F}_{\text {tabel }}=1,959$, karena $\mathrm{F}_{\text {hitung }}<\mathrm{F}_{\text {tabel }}$ maka data nilai tes II kelas eksperimen dan kelas kontrol dinyatakan homogen.

Hasil analisis data nilai tes I dari masing-masing kelas sebelum diberikan latihan soal terstruktur pada kelas eksperimen dan latihan soal pada kelas kontrol menunjukkan bahwa tes I pada kelas eksperimen maupun kelas kontrol tidak berbeda secara signifikan. Data yang diperoleh dianalisis menggunakan uji-t. Hasil perhitungan uji-t diperoleh $t_{\text {hitung }}=1,092$ sedangkan $t_{\text {tabel }}=1,675$ pada taraf signifikan $\alpha=0,05$ dan $\mathrm{dk}=\mathrm{n}_{1}+\mathrm{n}_{2}-2=28+25-2=51$, karena $\mathrm{t}_{\text {hitung }}<\mathrm{t}_{\text {tabel }}$, maka $\mathrm{H}_{0}$ diterima dan $\mathrm{H}_{\mathrm{a}}$ ditolak, dengan demikian dapat disimpulkan bahwa sebelum diberikan latihan soal pemahaman konsep bilangan kuantum siswa kelas eksperimen tidak berbeda dengan siswa kelas kontrol atau dinyatakan seimbang.

Hasil perhitungan uji-t diperoleh $t_{\text {hitung }}=3,06$ sedangkan $t_{\text {tabel }}=1,675$ pada taraf signifikan $\alpha=0,05$ dan $\mathrm{dk}=\mathrm{n}_{1}+\mathrm{n}_{2}-2=28+25-2=51$, karena $\mathrm{t}_{\text {hitung }}>$ $\mathrm{t}_{\text {tabel }}$ maka Ho ditolak dan Ha diterima, dengan demikian dapat disimpulkan bahwa pemberian latihan soal terstruktur setelah pembelajaran langsung berpengaruh terhadap pemahaman konsep bilangan kuantum pada siswa kelas $\mathrm{X}$ MIPA SMAN 1 Palangka Raya tahun ajaran 2018/2019.

Tujuan dari penelitian ini untuk menganalisis pengaruh hasil belajar antara kelas yang menggunakan latihan soal terstruktur dengan kelas yang menggunakan latihan soal. Persentase pemahaman konsep siswa kelas eksperimen dan kelas kontrol yang paling tinggi terdapat pada butir soal nomor 1 pada kelas eskperimen mengalami peningkatan yang lebih tinggi sebesar 90,63\% dibandingkan kelas kontrol sebesar 74\%. Persentase pemahaman konsep siswa pada kelas eksperimen dan kelas kontrol pada butir soal nomor 2 pada kelas eksperimen mengalami peningkatan sebesar $87,50 \%$ dibandingkan kelas kontrol sebesar $76 \%$. Persentase pemahaman konsep siswa pada kelas eksperimen dan kelas kontrol pada butir soal nomor 3 pada kelas eksperimen mengalami peningkatan sebesar 79,91\% dibandingkan kelas kontrol sebesar 59,5\%. Persentase pemahaman konsep siswa pada kelas eksperimen dan kelas kontrol pada butir soal nomor 4 pada kelas eksperimen mengalami peningkatan sebesar 26,19\% dibandingkan kelas kontrol sebesar 13,33\%. Hal ini membuktikan bahwa pada kelas eksperimen yang menggunakan latihan soal terstruktur lebih mampu meningkatkan pemahaman konsep siswa dibandingkan kelas kontrol.

Dasar dalam penentuan siswa kelompok atas dan siswa kelompok bawah yaitu hasil nilai ulangan harian yang diperoleh dari guru mata pelajaran di sekolah tempat penelitian. Berdasarkan hasil perhitungan, pada kelas eksperimen $28 \mathrm{x}$ $27 \%=7,56$ dan pada kelas kontrol $25 \times 27 \%=6,75$ maka diambil 7 orang siswa dari kelompok atas dan 7 orang siswa dari kelompok bawah pada kelas eskperimen dan kontrol.

Pemahaman konsep siswa dalam menentukan bilangan kuantum (n, $\ell, \mathrm{m}$ dan s) pada elektron terakhir untuk subkulit $\mathrm{p}$ atau $\mathrm{s}$ suatu atom ditelusuri menggunakan butir soal 1 . 
Tabel 5. Sebaran Skor Tes I-Tes II Siswa Kelompok Atas dan Kelompok Bawah Kelompok Atas

\begin{tabular}{|c|c|c|c|c|c|c|c|}
\hline \multicolumn{8}{|c|}{ Kelas Eksperimen } \\
\hline \multicolumn{2}{|c|}{ Tes I } & \multicolumn{2}{|c|}{ Tes II } & \multicolumn{2}{|c|}{ Tes I } & \multicolumn{2}{|c|}{ Tes II } \\
\hline Skor & $\sum$ Siswa & Skor & $\sum_{\text {wa }}^{\sum_{\text {Sis }}}$ & Skor & $\sum$ Siswa & Skor & $\sum$ Siswa \\
\hline 3 & 3 & 4 & 3 & 2 & 1 & 4 & 1 \\
\hline 3,5 & 2 & 4 & 2 & 2,5 & 1 & 4 & 1 \\
\hline \multirow[t]{4}{*}{4} & 2 & 4 & 2 & 3 & 1 & 4 & 1 \\
\hline & & & & \multirow{2}{*}{3,5} & \multirow{2}{*}{2} & 3,5 & 1 \\
\hline & & & & & & 4 & 1 \\
\hline & & & & 4 & 2 & 4 & 2 \\
\hline
\end{tabular}

\begin{tabular}{|c|c|c|c|c|c|c|c|}
\hline \multicolumn{8}{|c|}{ Kelompok Bawah } \\
\hline \multicolumn{4}{|c|}{ Kelas Eksperimen } & \multicolumn{4}{|c|}{ Kelas Kontrol } \\
\hline \multicolumn{2}{|c|}{ Tes I } & \multicolumn{2}{|c|}{ Tes II } & \multicolumn{2}{|c|}{ Tes I } & \multicolumn{2}{|c|}{ Tes II } \\
\hline Skor & $\sum$ Siswa & Skor & $\begin{array}{c}\sum \text { Sis } \\
\text { wa }\end{array}$ & Skor & $\begin{array}{c}\sum \text { Sis } \\
\text { wa }\end{array}$ & Skor & $\sum$ Siswa \\
\hline \multirow{5}{*}{$` 1$} & \multirow{5}{*}{6} & 0 & 1 & \multirow{3}{*}{1} & \multirow{3}{*}{6} & 2 & 1 \\
\hline & & 2 & 1 & & & 2,5 & 4 \\
\hline & & 3 & 2 & & & 3 & 1 \\
\hline & & 3,5 & 1 & \multirow{3}{*}{2} & \multirow{3}{*}{1} & \multirow{3}{*}{2} & \multirow{3}{*}{1} \\
\hline & & 4 & 1 & & & & \\
\hline 2 & 1 & 2,5 & 1 & & & & \\
\hline
\end{tabular}

Berdasarkan hasil yang diperoleh kelas eksperimen dan kelas kontrol, jumlah siswa yang memperoleh skor maksimal pembelajaran menggunakan latihan soal terstruktur lebih banyak dari pembelajaran menggunakan latihan soal. Artinya pembelajaran langsung tentang bilangan kuantum kelas eksperimen lebih baik dibanding kelas kontrol.

Tabel 6. Contoh Jawaban Siswa Kelas Eksperimen dan Kelas Kontrol yang Dominan pada Indikator 1 Tujuan 1

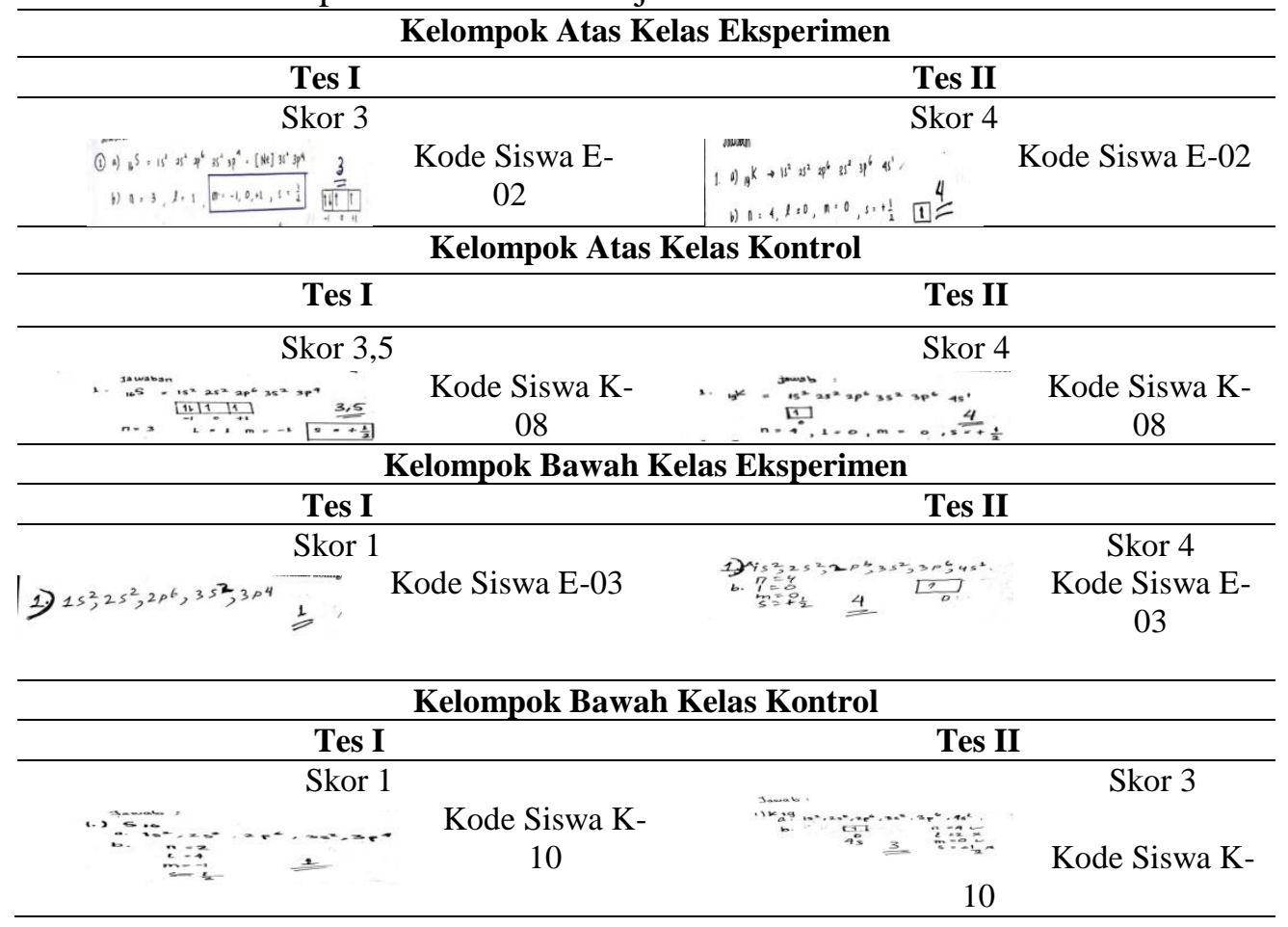


Tabel 6 menunjukkan perbedaan hasil tes II siswa kelompok bawah kelas eksperimen dan kelas kontrol. Perbedaan hasil tes II berhubungan dengan perbedaan perlakuan antara pada kelas eksperimen dan kelas kontrol. Pada gambar 2 dan gambar 3, dimana siswa kode E-02 perwakilan kelompok atas kelas eksperimen dan kode K-08 perwakilan kelompok atas kelas kontrol serta siswa kode E-03 perwakilan kelompok bawah kelas eksperimen yang dapat menentukan bilangan kuantum elektron terakhir ( $\mathrm{n}, \ell, \mathrm{m}$ dan $\mathrm{s}$ ) pada subkulit $\mathrm{s}$ suatu atom sedangkan siswa dengan kode K-10 yang mewakili kelompok bawah kelas kontrol hanya dapat menentukan dua bilangan kuantum yaitu $\mathrm{n}$ dan $\mathrm{m}$ saja.

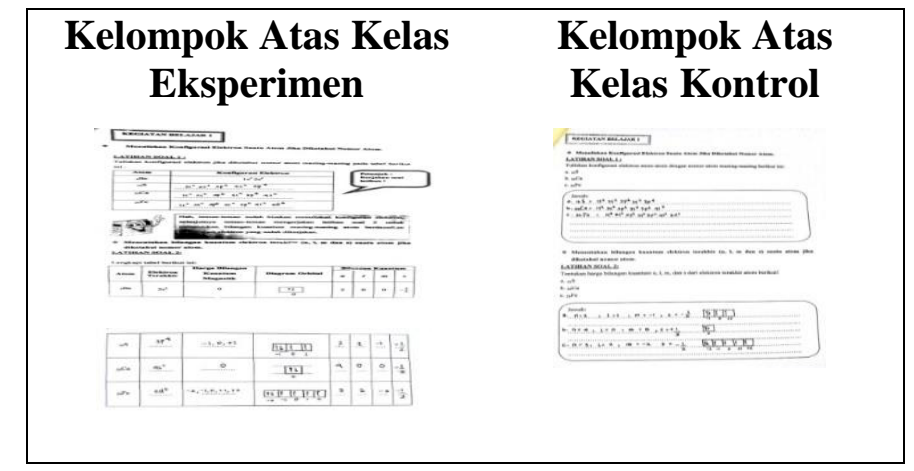

Gambar 2. Contoh Jawaban Siswa Kelompok Atas pada Indikator 1 Tujuan 1

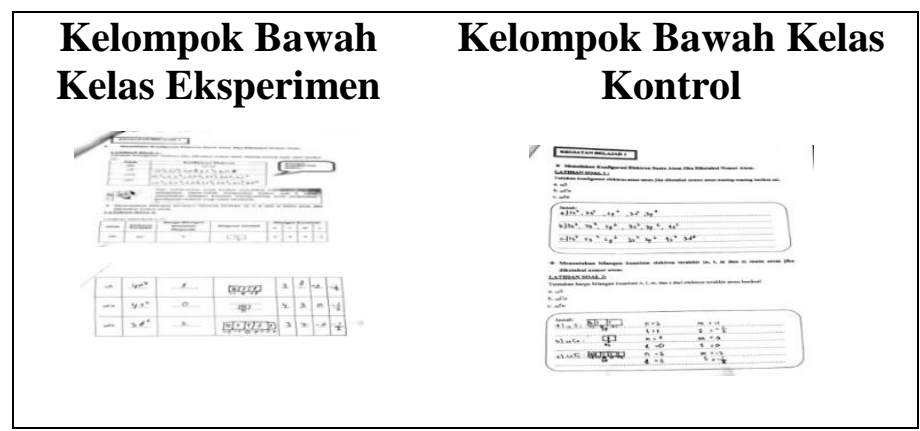

Gambar 3. Contoh Jawaban Siswa Kelompok Bawah pada Indikator 1 Tujuan 1

Pemahaman konsep siswa dalam menentukan bilangan kuantum $(\mathrm{n}, \ell, \mathrm{m}$ dan s) pada elektron terakhir untuk subkulit $d$ suatu atom ditelusuri menggunakan butir soal nomor 2 .

Tabel 7. Sebaran Skor Tes I-Tes II Siswa Kelompok Atas dan Kelompok Bawah

\begin{tabular}{ccccccccc}
\hline \multicolumn{9}{c}{ Kelompok Atas } \\
\hline \multicolumn{3}{c}{ Kelas Eksperimen } & \multicolumn{4}{c}{ Kelas Kontrol } \\
\hline \multicolumn{2}{c}{ Tes I } & \multicolumn{2}{c}{ Tes II } & \multicolumn{2}{c}{ Tes I } & \multicolumn{2}{c}{ Tes II } \\
\hline Skor & $\sum$ Siswa & Skor & $\sum$ Siswa & Skor & $\sum$ Siswa & Skor & $\sum$ Siswa \\
\hline 0 & 1 & 4 & 1 & 0 & $l$ & 3,5 & 1 \\
\hline 3 & 2 & 4 & 2 & $l$ & 1 & 4 & 1 \\
\hline 3,5 & 2 & 4 & 2 & 2,5 & 1 & 4 & 1 \\
\hline 4 & 2 & 4 & 2 & 3 & 1 & 4 & 1 \\
\hline & & & & 3,5 & 1 & 4 & 1 \\
\hline & & & 4 & 2 & 4 & 2 \\
\hline
\end{tabular}




\begin{tabular}{|c|c|c|c|c|c|c|c|}
\hline \multicolumn{8}{|c|}{ Kelompok Bawah } \\
\hline \multicolumn{4}{|c|}{ Kelas Eksperimen } & \multicolumn{4}{|c|}{ Kelas Kontrol } \\
\hline \multicolumn{2}{|c|}{ Tes I } & \multicolumn{2}{|c|}{ Tes II } & \multicolumn{2}{|c|}{ Tes I } & \multicolumn{2}{|c|}{ Tes II } \\
\hline Skor & $\sum$ Siswa & Skor & $\sum$ Siswa & Skor & ¿Siswa & Skor & $\sum$ Siswa \\
\hline \multirow[t]{2}{*}{0} & \multirow[t]{2}{*}{3} & 1 & 1 & \multirow[t]{3}{*}{0} & \multirow[t]{3}{*}{4} & 1 & 1 \\
\hline & & 3 & 2 & & & 2 & 2 \\
\hline \multirow[t]{2}{*}{1} & \multirow[t]{2}{*}{3} & 2 & 2 & & & 2,5 & 1 \\
\hline & & 3 & 1 & 1 & 3 & 2 & 1 \\
\hline \multirow[t]{2}{*}{2} & \multirow[t]{2}{*}{1} & \multirow[t]{2}{*}{2,5} & \multirow[t]{2}{*}{1} & & & 2,5 & 1 \\
\hline & & & & & & 3 & 1 \\
\hline
\end{tabular}

Berdasarkan hasil yang diperoleh kelas eksperimen dan kelas kontrol, jumlah siswa yang memperoleh skor maksimal pembelajaran menggunakan latihan soal terstruktur lebih banyak dari pembelajaran menggunakan latihan soal. Artinya pembelajaran langsung tentang bilangan kuantum kelas eksperimen lebih baik dibanding kelas kontrol.

Tabel 8. Contoh Jawaban Siswa Kelas Eksperimen dan Kelas Kontrol yang Domain pada Indikator 1 Tujuan 2

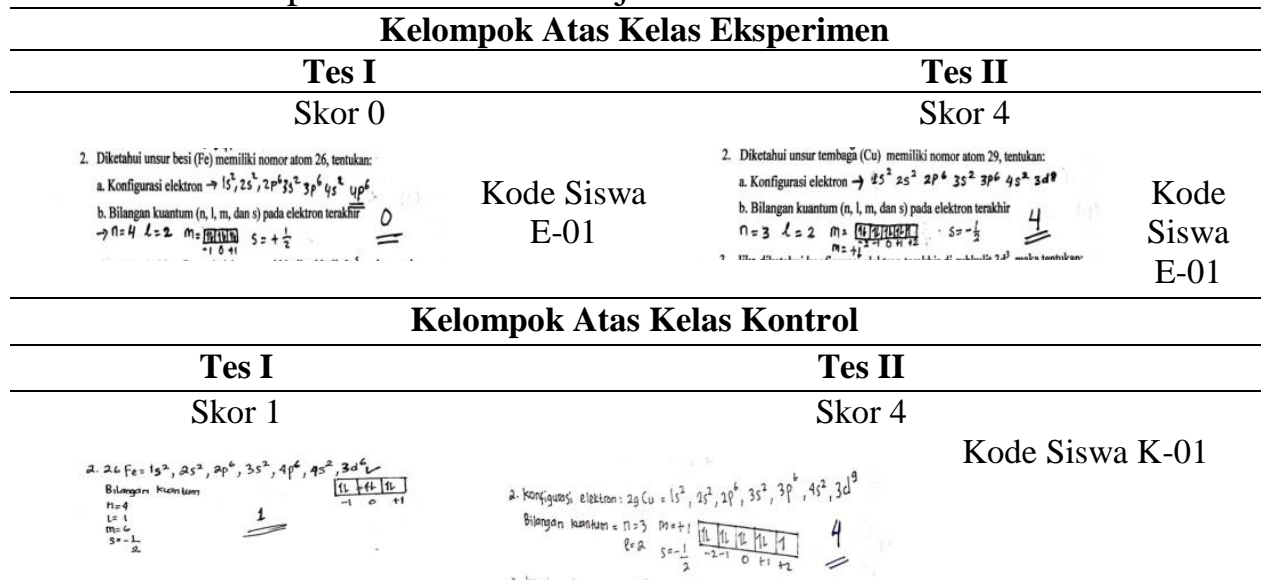

Kode Siswa K-01

\begin{tabular}{|c|c|c|}
\hline \multicolumn{3}{|c|}{ Kelompok Bawah Kelas Eksperimen } \\
\hline Tes I & \multicolumn{2}{|c|}{ Tes II } \\
\hline & \multicolumn{2}{|c|}{ Skor 3} \\
\hline 2. a. $26 \mathrm{fe}=[\mathrm{Ar}] 3 \mathrm{~d}^{8} 4 \mathrm{~s}^{2}$ & \multirow{3}{*}{ 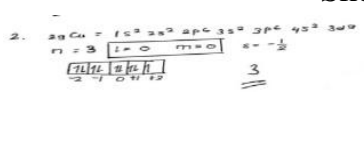 } & \multirow[t]{3}{*}{ Kode Siswa E-28 } \\
\hline Skor $0=$ & & \\
\hline Kode Siswa E-28 & & \\
\hline \multicolumn{3}{|c|}{ Kelompok Bawah Kelas Kontrol } \\
\hline Tes I & \multicolumn{2}{|c|}{ Tes II } \\
\hline Skor 0 & \multicolumn{2}{|c|}{ Skor 2,5} \\
\hline 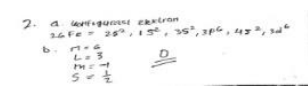 & 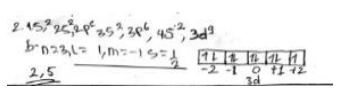 & \multirow[t]{2}{*}{ Kode Siswa K-09 } \\
\hline Kode Siswa K-09 & & \\
\hline
\end{tabular}

Tabel 8 menunjukkan perbedaan hasil tes II siswa kelompok bawah kelas eksperimen dan kelas kontrol. Perbedaan hasil tes II berhubungan dengan perbedaan perlakuan pada kelas eksperimen dan kelas kontrol. Pada latihan soal 
yang disajikan pada gambar 4 dan gambar 5, dimana siswa kode E-01 perwakilan kelompok atas kelas eksperimen dan kode K-01 perwakilan kelompok atas kelas kontrol dapat menentukan bilangan kuantum elektron terakhir (n, l, m dan s) pada subkulit d suatu atom, siswa dengan kode E-28 yang mewakili kelompok bawah kelas eksperimen hanya dapat menentukan dua bilangan kuantum yaitu $\mathrm{n}$ dan $\mathrm{s}$ saja. Sedangkan siswa dengan kode K-09 perwakilan kelompok bawah kelas kontrol hanya dapat menentukan salah satu bilangan kuantum.

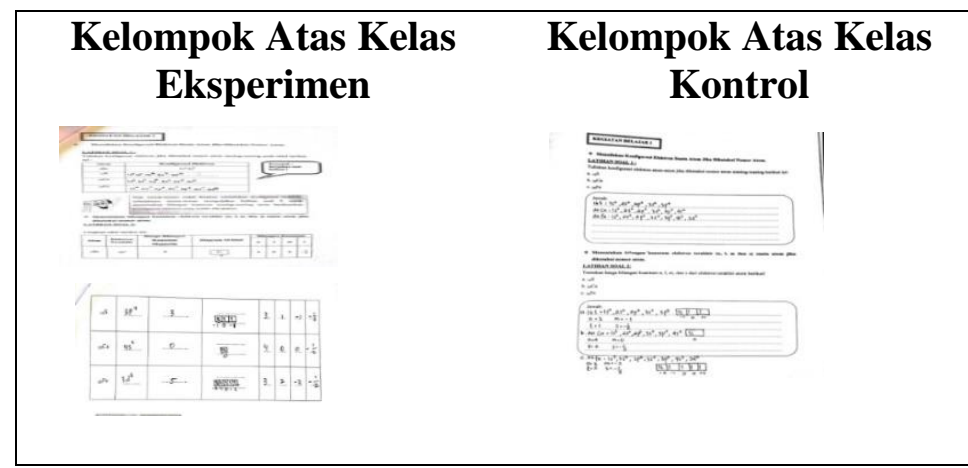

Gambar 4. Contoh Jawaban Siswa Kelompok Atas pada Indikator 1 Tujuan 2

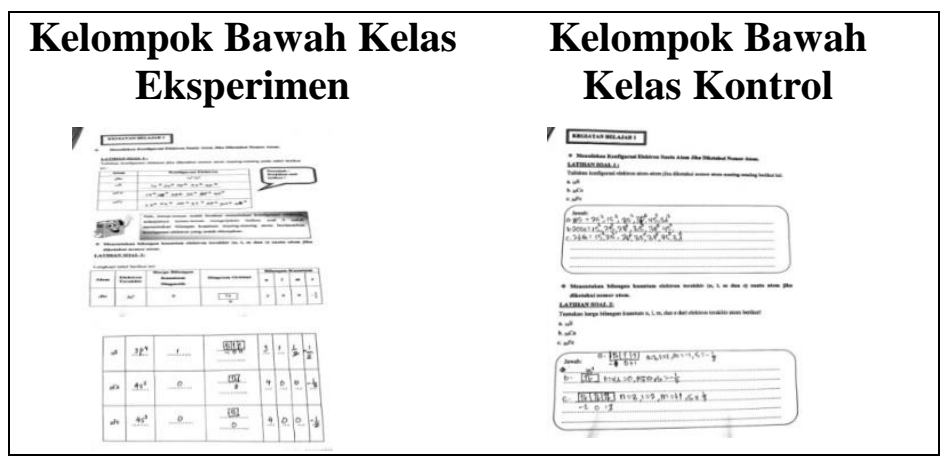

Gambar 5. Contoh Jawaban Siswa Kelompok Bawah pada Indikator 1 Tujuan 2

Tabel 9. Sebaran Skor Tes I-Tes II Siswa Kelompok Atas dan Kelompok Bawah

\begin{tabular}{|c|c|c|c|c|c|c|c|}
\hline \multicolumn{8}{|c|}{ Kelompok Atas } \\
\hline \multicolumn{4}{|c|}{ Kelas Eksperimen } & \multicolumn{4}{|c|}{ Kelas Kontrol } \\
\hline \multicolumn{2}{|c|}{ Tes I } & \multicolumn{2}{|c|}{ Tes II } & \multirow{2}{*}{$\begin{array}{l}\text { Tes I } \\
\text { Skor }\end{array}$} & \multicolumn{3}{|c|}{ Tes II } \\
\hline Skor & $\sum$ Siswa & Skor & $\sum$ Siswa & & $\sum$ Siswa & Skor & $\sum$ Siswa \\
\hline 0 & 1 & 4 & 1 & 0 & 1 & 3 & 1 \\
\hline 2 & 1 & 4 & 1 & 1 & 1 & 3,5 & 1 \\
\hline 3,5 & 3 & 4 & 3 & 3 & 1 & 3,5 & 1 \\
\hline \multirow[t]{3}{*}{4} & 2 & 4 & 2 & 35 & 3 & 3,5 & 1 \\
\hline & & & & & & 4 & 2 \\
\hline & & & & 4 & 1 & 3 & 1 \\
\hline \multicolumn{8}{|c|}{ Kelompok Bawah } \\
\hline \multicolumn{4}{|c|}{ Kelas Eksperimen } & \multicolumn{4}{|c|}{ Kelas Kontrol } \\
\hline \multicolumn{2}{|c|}{ Tes I } & \multicolumn{2}{|c|}{ Tes II } & \multicolumn{2}{|c|}{ Tes I } & \multicolumn{2}{|c|}{ Tes II } \\
\hline Skor & $\sum$ Siswa & Skor & $\sum$ Siswa & Skor & $\sum$ Siswa & Skor & $\sum$ Siswa \\
\hline \multirow{3}{*}{0} & & 0 & 1 & \multirow{3}{*}{0} & \multirow{3}{*}{7} & 0 & 3 \\
\hline & 4 & 1 & 2 & & & 1 & 1 \\
\hline & & 2,5 & 1 & & & 2 & 2 \\
\hline
\end{tabular}




\begin{tabular}{cccccc}
\hline 1 & 2 & 2 & 1 & 2,5 & 1 \\
& & 2,5 & 1 & & \\
2 & 1 & 2,5 & 1 & & \\
\hline
\end{tabular}

Pemahaman konsep siswa dalam menentukan bilangan kuantum elektron terakhir ( $\mathrm{n}, \ell, \mathrm{m}$ dan $\mathrm{s})$ jika diketahui elektron terakhir ditelusuri menggunakan butir soal nomor 3. Berdasarkan hasil yang diperoleh kelas eksperimen dan kelas kontrol, jumlah siswa yang memperoleh skor maksimal pembelajaran menggunakan latihan soal terstruktur lebih banyak dari pembelajaran menggunakan latihan soal. Artinya pembelajaran langsung tentang bilangan kuantum kelas eksperimen lebih baik dibanding kelas kontrol.

Tabel 10. Contoh Jawaban Siswa Kelas Eksperimen dan Kelas Kontrol yang Domain pada Indikator 2 Tujuan 3

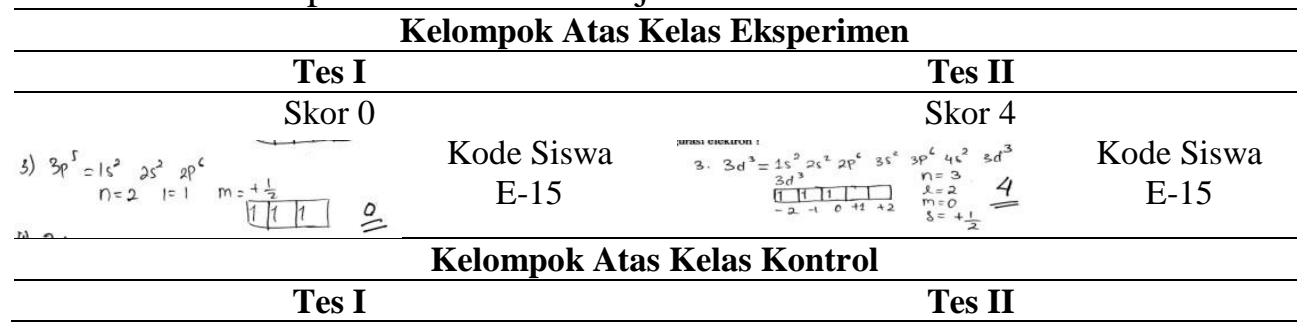

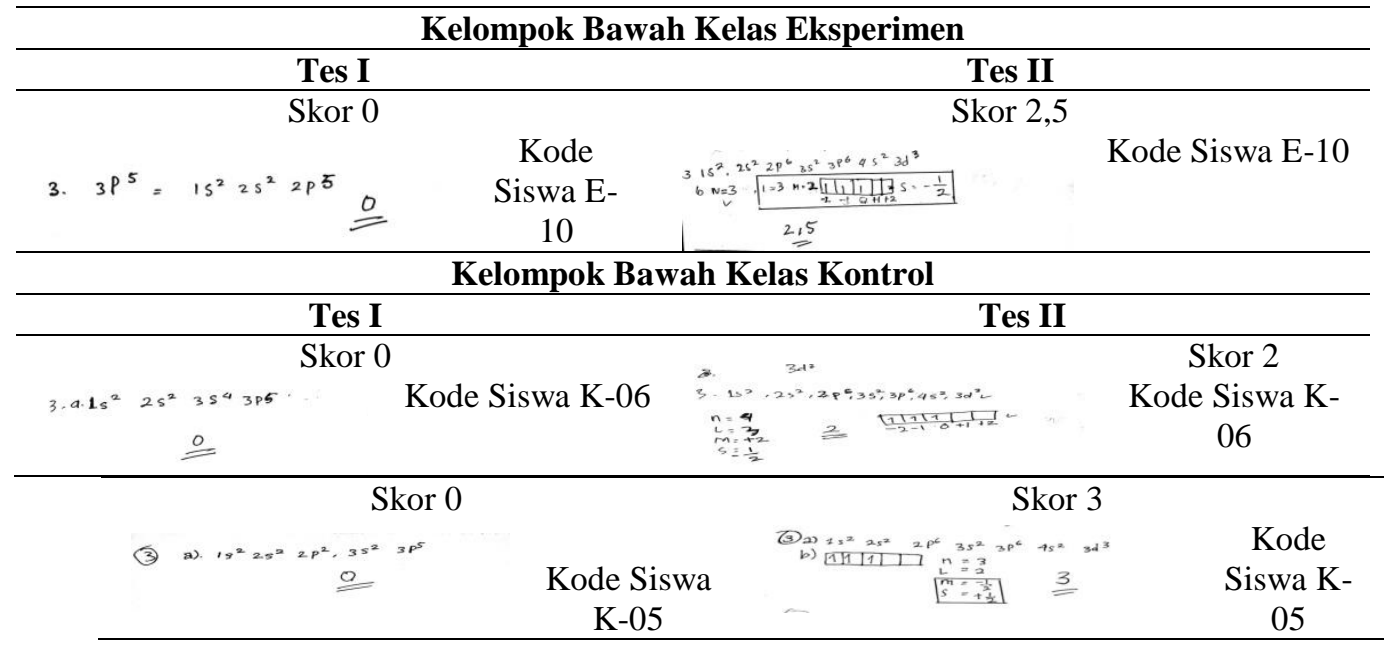

Tabel 10 menunjukkan perbedaan hasil tes II siswa kelompok atas dan kelompok bawah kelas eksperimen dan kelas kontrol. Perbedaan hasil tes II berhubungan dengan perbedaan perlakuan antara pada kelas eksperimen dan kelas kontrol. Pekerjaan siswa pada latihan soal yang disajikan pada gambar 6 dan 7, dimana siswa kode E-15 perwakilan kelompok atas kelas eksperimen dapat menentukan keempat bilangan kuantum, kode K-05 perwakilan kelompok atas kelas kontrol hanya dapat menentukan dua bilangan kuantum, siswa kode E-10 perwakilan kelompok bawah kelas eksperimen yang hanya dapat menentukan salah satu bilangan kuantum sedangkan siswa dengan kode K-10 yang mewakili kelompok bawah kelas kontrol hanya dapat menggambarkan orbital elektron terakhir. 


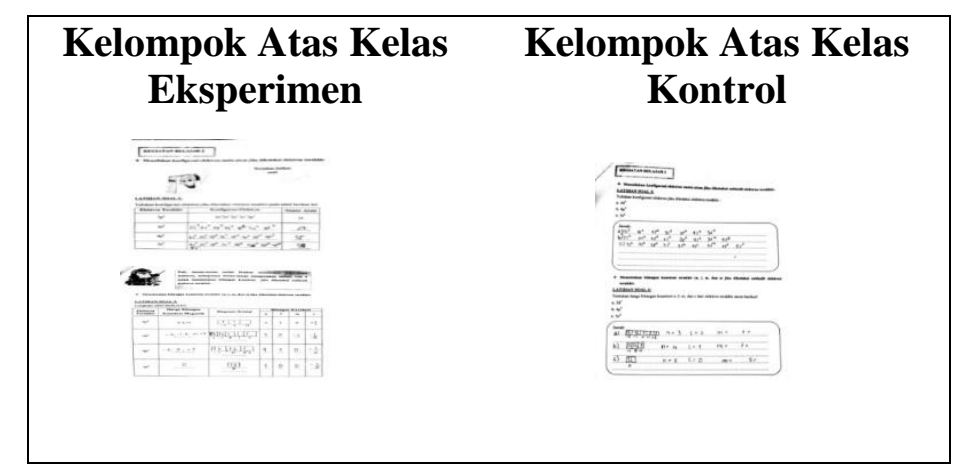

Gambar 6. Contoh Jawaban Siswa Kelompok Atas pada Indikator 2 Tujuan 3

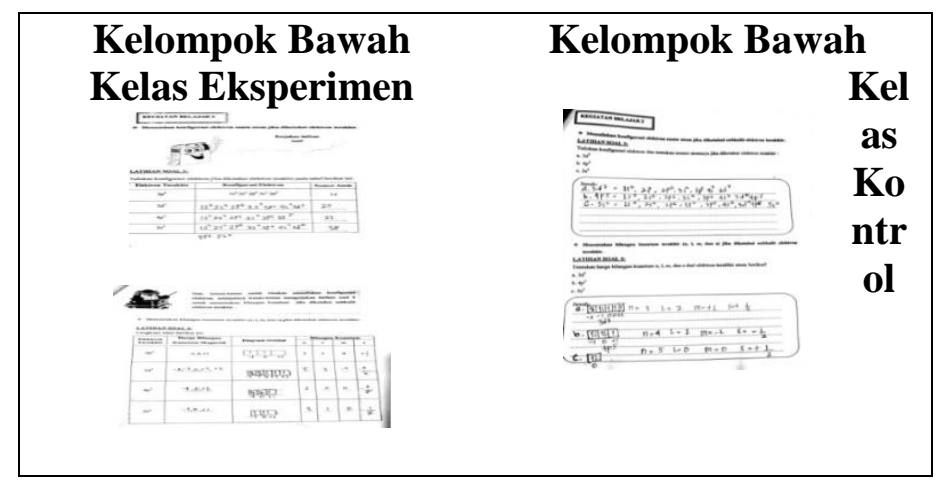

Gambar 7. Contoh Jawaban Siswa Kelompok Bawah pada Indikator 2 Tujuan 3

Pemahaman konsep siswa dalam menuliskan konfigurasi elektron suatu atom jika diketahui bilangan kuantum elektron terakhir ditelusuri menggunakan butir soal nomor 4.

Tabel 11. Sebaran Skor Tes I-Tes II Siswa Kelompok Atas dan Kelompok Bawah

\begin{tabular}{|c|c|c|c|c|c|c|c|}
\hline \multicolumn{8}{|c|}{ Kelompok Atas } \\
\hline \multicolumn{4}{|c|}{ Kelas Eksperimen } & \multicolumn{4}{|c|}{ Kelas Kontrol } \\
\hline \multicolumn{2}{|c|}{ Tes I } & \multicolumn{2}{|c|}{ Tes II } & \multicolumn{2}{|c|}{ Tes I } & \multicolumn{2}{|c|}{ Tes II } \\
\hline Skor & $\sum$ Siswa & Skor & $\sum$ Siswa & Skor & $\sum$ Siswa & Skor & SSiswa \\
\hline \multirow{4}{*}{0} & \multirow{4}{*}{4} & 0 & 1 & 0 & 3 & 0 & 3 \\
\hline & & 1 & 1 & 1 & 2 & 1 & 1 \\
\hline & & 2 & 1 & & & 3 & 1 \\
\hline & & 3 & 1 & 2 & 1 & 2 & 1 \\
\hline \multirow{2}{*}{2} & \multirow{2}{*}{3} & 2 & 1 & \multirow{2}{*}{3} & \multirow{2}{*}{1} & \multirow{2}{*}{3} & \multirow{2}{*}{1} \\
\hline & & 3 & 2 & & & & \\
\hline \multicolumn{8}{|c|}{ Kelompok Bawah } \\
\hline \multicolumn{4}{|c|}{ Kelas Eksperimen } & \multicolumn{4}{|c|}{ Kelas Kontrol } \\
\hline \multicolumn{2}{|c|}{ Tes I } & \multicolumn{2}{|c|}{ Tes II } & Tes I & \multirow{2}{*}{\multicolumn{2}{|c|}{$\begin{array}{l}\text { Tes II } \\
\text { Skor }\end{array}$}} & \\
\hline Skor & $\sum$ Siswa & Skor & $\sum$ Siswa & Skor & & & $\sum$ Siswa \\
\hline \multirow{2}{*}{0} & \multirow{2}{*}{7} & 0 & 3 & \multirow{2}{*}{0} & \multirow{2}{*}{7} & \multirow{2}{*}{0} & \multirow{2}{*}{7} \\
\hline & & 1 & 4 & & & & \\
\hline
\end{tabular}

Berdasarkan hasil yang diperoleh kelas eksperimen dan kelas kontrol, jumlah siswa yang memperoleh skor maksimal pembelajaran menggunakan latihan soal terstruktur lebih banyak dari pembelajaran menggunakan latihan soal. 
Artinya pembelajaran langsung tentang bilangan kuantum kelas eksperimen lebih baik dibanding kelas kontrol.

Tabel 12. Contoh Jawaban Siswa Kelas Eksperimen dan Kelas Kontrol yang Domain pada Indikator 3 Tujuan 4

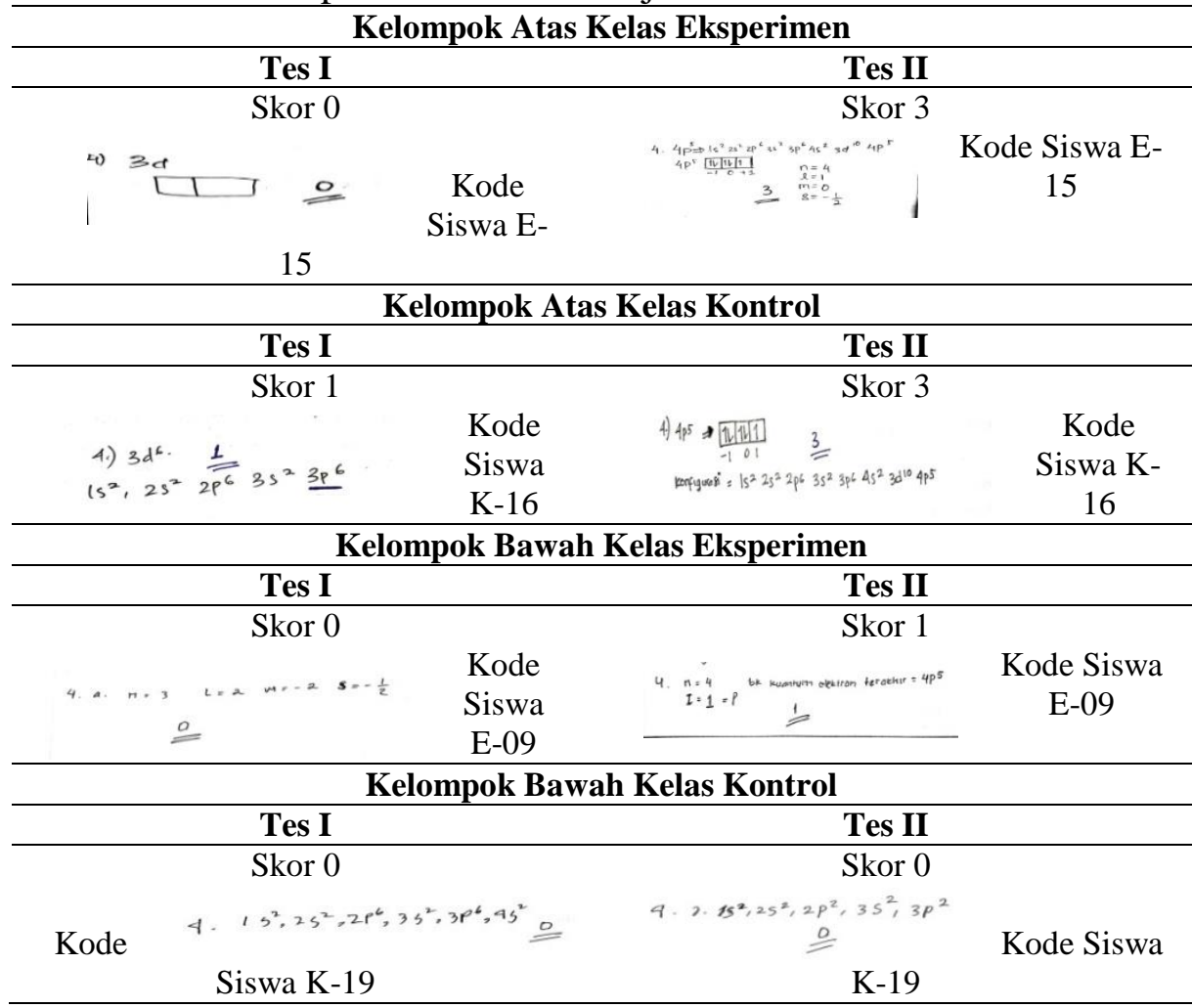

Tabel 12 menunjukkan perbedaan hasil tes II siswa kelompok bawah kelas eksperimen dan kelas kontrol. Perbedaan hasil tes II berhubungan dengan perbedaan perlakuan antara pada kelas eksperimen dan kelas kontrol. Pekerjaan siswa pada latihan soal yang disajikan pada gambar 8 dan 9, dimana siswa kode E-15 perwakilan kelompok atas kelas eksperimen dan kode K-16 perwakilan kelompok atas kelas kontrol dapat menuliskan konfigurasi elektron, siswa kode E09 perwakilan kelompok bawah kelas eksperimen yang dapat menentukan kulit dan subkulit elektron sedangkan siswa dengan kode K-19 yang mewakili kelompok bawah kelas kontrol tidak dapat menentukan kulit dan subkulit elektron.

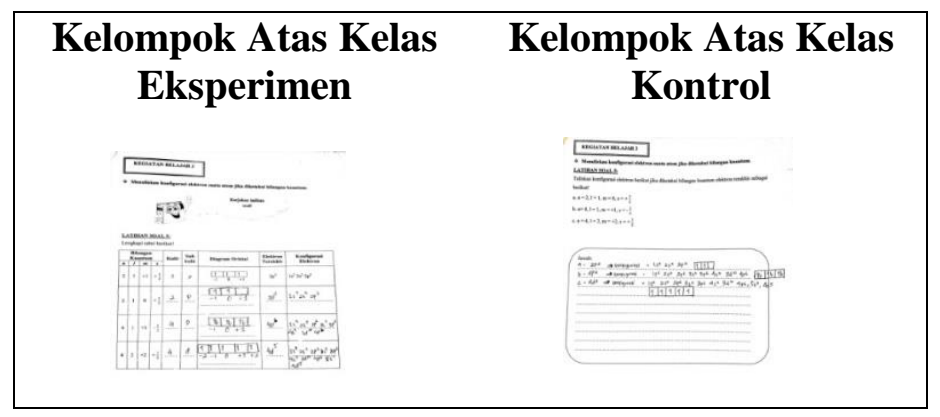

Gambar 8. Contoh Jawaban Siswa Kelompok Atas pada Indikator 3 Tujuan 4 


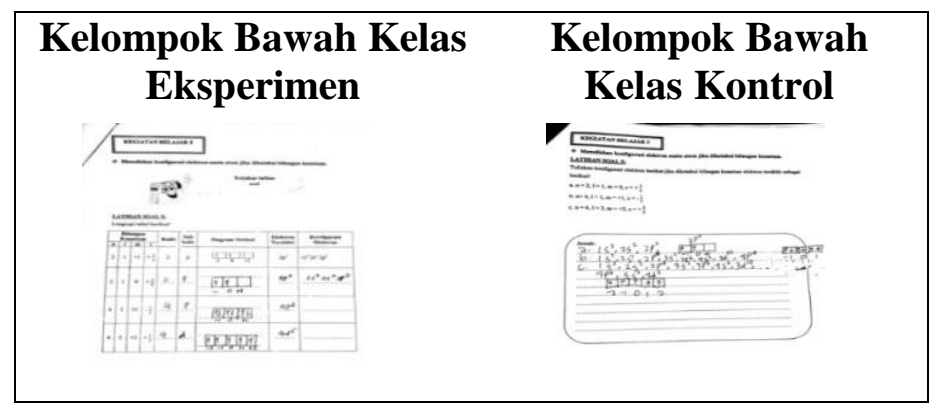

Gambar 9. Contoh Jawaban Siswa Kelompok Bawah pada Indikator 3 Tujuan 4

\section{Kesimpulan}

Berdasarkan hasil penelitian menunjukkan bahwa $t_{\text {hitung }}>t_{\text {tabel }}(3,06>$ 1,675) pada taraf signifikan 5\%. maka Ho ditolak dan Ha diterima, dengan demikian dapat disimpulkan bahwa pemberian latihan soal terstruktur setelah pembelajaran langsung berpengaruh terhadap pemahaman konsep bilangan kuantum pada siswa kelas X MIPA SMAN 1 Palangka Raya tahun ajaran $2018 / 2019$.

\section{Daftar Rujukan}

Abdillah, Husni. 2002. Pengertian Belajar dari Berbagai Sumber (Belajar dan Pembelajaran). Bandung: Alfabeta.

Arikunto, Suharsimi. 2000. Prosedur Suatu Pendekatan Praktek. Jakarta: Rinneka Cipta.

Arikunto, Suharsimi. 2006. Prosedur Penelitian Suatu Pendekatan Praktik. Jakarta: Rinneka Cipta.

Arikunto, Suharsimi. 2009. Dasar-Dasar Evaluasi Pendidikan. Jakarta: Bumi Aksara.

Aunurrahman. 2009. Belajar Dan Pembelajaran. Bandung: Alfabeta.

Chang, Raymond. 2003. Kimia Dasar Konsep-Konsep Inti Jilid I Edisi Ketiga. Jakarta: Erlangga.

Dahar, Ratna Wilis. 1989. Teori-Teori Belajar. Jakarta : Erlangga.

Departemen Pendidikan Nasional. 2003. Kurikulum 2004: Standar Kompetensi Mata Pelajaran Kimia. Jakarta: Departemen Pendidikan Nasional.

Harjanto. 2005. Perencanaan Pengajaran. Jakarta: Rineka Cipta.

Hidayanti, Nor. 2015. Interaksi Siswa dengan Sumber Belajar dalam Pembelajaran Struktur Atom dan Sistem Periodik Unsur Di Kelas X MIA-1 Negeri 2 Palangka Raya Tahun Ajaran 2014/2015. Palangka Raya: Universitas Palangka Raya.

Jufri, DR. H. A. W. 2013. Belajar dan Pembelajaran Sains. Bandung: Pustaka Reka Cipta.

Kontesa, Novi. 2016. Peningkatan Pemahaman Konsep pH Asam Lemah dan Basa Lemah Pasca Menggunakan Latihan Soal Terstruktur Pada Siswa Kelas XI IPA SMA Nusantara Palangka Raya Tahun Ajaran 2015/2016. Palangka Raya: Universitas Palangka Raya.

Mairing, Pasini Jackson. 2017. Statistika Pendidikan. Yogyakarta: Andi.

Petrucci, H Ralph. 1985. Kimia Dasar Prinsip Dan Terapan Modern Edisi Keempat Jilid 1. Bogor: Erlangga. 
Sari, Fitta Nurma. 2017. Pengaruh Penggunaan LKS terhadap Pemahaman Konsep Siswa Kelas X MIA 1 SMA Negeri 4 Muara Teweh Tahun Ajaran 2016/2017 Pada Materi Penentuan Bilangan Kuantum dan Letak Unsur dalam Sistem Periodik Unsur. Palangka Raya: Universitas Palangka Raya.

Shoimin, Aris. 2014. 68 Model Pembelajaran Inovatif dalam Kurikulum 2013. Yogyakarta: Ar-Ruzz Media.

Sion, Holten dkk. 2017. Pedoman Penulisan Skripsi. Palangka Raya: UPR.

Sugiyono. 2017. Statistika Untuk Pendidikan. Bandung: Alfabeta.

Suyanti, Dwi Retno. 2010. Strategi Pembelajaran Kimia. Yogyakarta: Graha Ilmu.

Trianto. 2009. Mendesain Model Pembelajaran Inovatif-Prograsif. Jakarta: Kencana Prenada Media Grup.

Wulandari, Tri Erna dkk. 2016. Kimia Peminatan Matematika dan Ilmu-Ilmu Alam SMA/MA Kelas X Semester 1. Klaten: PT Intan Pariwara. 